\title{
Production Costs Through the Light of The Economic Way of Thinking
}

\author{
Sergei Peregonchuk \\ The National University of Samoa \\ Samoa
}

\begin{abstract}
The paper critically examines the current method of teaching one of the core topics in Introductory Economics. The focus of the criticism of the traditional Production Costs theory as it had been taught in many universities across the world is that it inevitably creates in the minds of beginning students a false perception that "things have costs". The Economic Way of Thinking as the alternative approach to the traditional way of teaching Introductory Economics disarms this popular idea and affirms that "only actions have costs".
\end{abstract}

\section{Introduction}

If you flip through the pages of any classical textbook on Introductory Economics written by Mankiv, Krugman, Lipsey, Parkin or Layton and taught in North American, European or Australian universities you will discover that practically every page of it is riddled with formulas or graphs. Some Introductory Economics textbooks have been converted into a course on analytic geometry or calculus. I would not see any problems with this approach if all the beginning students were destined to apply to graduate schools and pass $\mathrm{PhD}$ exams. But in reality, only a few of them follow that path.

In this paper I want to examine critically the current traditional method of teaching one of the fundamental topics in Introductory Economics course - Production Costs- to identify the consequences of that approach on the application of the Production Costs concept to everyday economic and social issues. After studying this topic using one of the classical textbooks that represent The Traditional Approach the beginning students will be able to derive rigorously the behaviour of the marginal and the average cost curves. They get a good understanding of the relationship between these two types of costs. Students also can-do calculation of different elements of costs of production and they are equipped well enough to express them in monerary terms. But they have no clue how to apply that knowledge to everyday practice of business firms. And not because they did not grasp well enough the production costs theory but because that theory by its nature - which is perfectly flawless in the realm of its assumptions - can not be immediately applied to real world issues. That is why many students who successfully passed "rigorous" economics tests based on the use of math failed the tests when they asked to apply the principle of opportunity cost to everyday economic problems.

\section{Process of formation of notions of "things" and "costs" in the mind of John Smith}

To justify the basic thesis of the article that the traditional economic theory set forth in the popular textbooks on Principles of Economics forms a false idea in the consciousness of students that "things have costs" we invite our reader to an exciting journey to trace back the evolution of these notions in the mind of our personage John Smith. In this investigation we will base ourselves on the generally accepted scientific truths set forth in the works of the prominent psychologists as Ivan Pavlov, Jean Piaget, Lev Vygotsky, Kurt Levin, John B. Watson, Edward Thorndike, Burrhus Skinner, Clark Hull, Ernst Meumann.

Let us start our journey. Imagine that our hero John Smith has turned 1.5 years a few days ago and his parents has decided to celebrate this event in the Chinook shopping mall having taken their kid with them. Let us carefully watch the behaviour of that little toddler. The Chinook shopping mall is a kingdom of things. They as though talk to our little John and say to him:" Look at us how beautiful we are, how attractive we are. Touch us, take us into your hands". John stretches out his little hands to an every thing hot having the ability to resist that magic force which those things have on him. All of a sudden, his attention is captures by a bright coloured car model "Jaguar". As if under its spell he is stiffen with astonishment not taking away his eyes from that "Jaguar". If you had a chance to look at the eyes of our hero at that moment then you would see in them such passion and fire which would be in the eyes of a gold-digger who had spent all his life searching for the treasures and, finally, had discovered a trunk with the precious bars in the Alaska's dark and wet cave. But the perambulator is moving ahead and John's attention is captured by the variegated rubber balls hanging on a cord. At this moment John has totally forgot about the magic "Jaguar". Now he is totally under the power of these balls.

What is behind such a behaviour of 1.5 years old child? Piaget [28] and Vygotsky [44] stated that the 
main distinguishing feature of that kind of a behavior is the origin in the consciousness of a child the unity between sensors and motor functions. Bee Helen in her well-known book "Lifespan Development" says, that in Piaget's view a little child is "entirely tied to the immediate present, responding to whatever stimulus available. She forgets events from one encounter to the next and does not appear to plan... Piaget thought that the baby still does not have mental symbols to stand for objects..." [11].

The perception of the 1.5 years old John is totally tied up by a specific situation in which he currently finds himself. He can bring nothing into it. When John looks at "Jaguar" he sees only this car model- its color, form, position in the space and etc. In his consciousness there is no imagination separated from the situation in which he finds himself. John is totally under the spell of "Jaguar". The fact that this "Jaguar" is a model of a car as means of conveyance our little John does not realize. "Jaguar" for him is only a brightly-colored object from which comes out a magic and powerful force that says to him:" Take me into your hands, touch me, I am so beautiful". Therefore, based on what we discussed above, we can contend that at this stage of development there are no notions of "things" and "costs" in John's consciousness. Only later the outer reality will become for him the world of things having a certain sense.

At this point we can see a question arising in the mind of our reader:" When do things become sensible in the mind of a child? How does the transition from the directly visual perception to a sensible perception take place in the consciousness of a child?". The fundamental changes in a child's perception occurs with the origin of a speech. Speech makes the change in the structure of perception bringing an element of reasonableness. With the help of a speech a child for the first time in his life puts an order into the world of things so that things assume a certain meaning.

Due to the purpose of our research paper we can distinguish between two stages in the development of a child's speech. The words of a child of up to 3 years old are tied closely to the specific situation or to the specific object to which these words are related. The separation of a word from the object does not exist yet. There is always an object behind the word. One of the most important characteristics of speech in that period of a child's development is that speech is not recognized. Our little John speaks but “...he does not recognize that he speaks" [44].

The fundamental change occurs when a child reaches the period between 3-8 years of age. By this time, he is able to separate a word from the object related to this word - speech becomes means of generalized perception. This intelligent generalized perception gives our little hero an ability to see in an object which takes his attention something more than it is contained in his direct visual act. Here we observe the origin of a totally different kind of a vision which is largely an abstraction. That type of perception already contains footprints of generalizations.

When our 1.5 years old John was looking at "Jaguar" - its color, its form, its position in the space was reflected on the retina of his eyes. He was drawing his little hands towards the car model trying to touch it not because he knew what a car is and what a function it can serve for him. John desperately desired to touch "Jaguar" only because there was the strong magic pulling force coming from the model. John could not resist that power. But when now our 5 years old John is looking at the same "Jaguar", he sees in it not only its outer characteristics - its color, its wheels, its roof and etc. The first thing that John now sees in "Jaguar" is that it is means of conveyance. The visual act of perception of this specific model is taking place simultaneously with the intelligent, generalized perception of "Jaguar" as a representative of a certain class of things.

We are coming now to a very important point in our research paper concluding that the origin of speech and the intelligent, generalized perception represent the beginning of a process of formation of notions in the consciousness of a child. This process has its own logic and can be divided into two stages:

1) development of a spontaneous (worldly) notion;

2) development of a scientific notion [40].

To understand better how notions are formed in our consciousness we will switch attention of our reader to the role of memory in that process. It is known that memory as the complex psychological process consists of a number of moments. The most important of them is the fixing of a reaction - the presence of a nerve footprint from a certain irritant. Physiologists and psychologists confirmed long ago that any reaction to an outward irritant does not disappear but is saved in our consciousness. Therefore, every trip of John's parents to the Chinook shopping mall inevitably left its footprint in John's memory - in his nerve track named "things-money". The shopping mall was a peculiar school where the notions of "things" and "money" and their interdependence were forming in the mind of our hero. We can consider the learning experience that our little John was obtaining in the mall as a process of fixing in his consciousness his reactions to the numerous acts of "buying-selling". Without that training our hero would not been able to ask his Dad - for the first time in his life- that momentous question about 50 cents. There would not exist the material prerequisite for that event - the beaten nerve track called "things-money". John's words:" Dad, could you give me, please, 50 cents to buy my favorite icecream?" were just a reproduction of the reactions already fixed in his nerve system due to the previous training in his school of life called the Chinook 
shopping mall. These words provide us with an undeniable evidence of formation of notions "things" and "money" and their tight interdependence in the consciousness of 5 years old John.

The qualitative change in the content of the notion of "costs" takes place in John's consciousness later on as a result of another momentous event in John's life - 12 years old John decides that he is old enough to earn money. He starts his work history by delivering flyers in his neighborhood. The dramatic change in John's social status inevitable produces the appropriate changes in his consciousness. When 5 years old John obtained his favorite ice-cream using his Dad's money then the notion of "costs" as something associated with "losses could not have been formed in his mind. There were no material prerequisites for that. Money which his Dad gave him were not associated in his mind with "loss". Quite contrary - Dad's money were "benefits" for John. But when John began to spend money earned by his own labor, the spontaneous notion of "costs" which appeared before in the form of the notion of "money" has changed its nature dramatically. Every time when John was taking $\$ 2$ from his own pocket to pay for his favorite strawberry ice-cream (due to the ongoing inflation) this money was reflected in his consciousness as real "loss". But "loss" is a worldly notion which forms the basis of the notion of "costs" and represents the nature of it. We observe here the process of transformation of the embryonic form of the notion of "costs" into its fully-fledged, complete form. Therefore, we can conclude that at this age the idea that "things have costs" has been firmly rooted in John's mind.

\section{Do "Things" Have Costs? The Traditional Theory of Production Costs}

The idea that "things have costs" has been strengthened further in the mind of our hero when he was taking Intro Microeconomics during his undergraduate studies. Let us walk together through the relevant pages of the most popular in North America textbooks written by G. Mankiw. He starts the section "Production and Costs" with the introduction of the core element of the theory of the costs of production - Production Function defining it as "the relationship between quantity of inputs used to make a good and the quantity of output of that good" [23]. In the paragraph "From the Production Function to The Total-Cost Curve" G. Mankiw explains how the information about firm's inputs and output can be translated into the information about costs. He begins with the presentation of "totals": "... total cost can be divided into two types. Some costs, called fixed costs, do not vary with the quantity of $\boldsymbol{O U T P U T}$ produced. They are incurred even if the firm produces nothing at all... Some of the firm's costs, called variable costs, change as the firm alters the quantity of OUTPUT produced." [23]

Having defined "totals" the author gives definitions of different "averages":" Total cost divided by the quantity of $\boldsymbol{O U T P U T}$ is called average total cost. Because total cost is the sum of fixed and variable costs, average total cost can be expressed as the sum of average fixed cost and average variable cost. Average fixed cost is the fixed cost divided by the quantity of $\boldsymbol{O U T P U T}$, and average variable cost is the variable cost divided by the quantity of OUTPUT' [23].

Now let us carefully analyse the above definitions of costs trying to identify the nature of all of them. For that purpose, I am going to ask you a couple of questions which will help you to accomplish that task: "What is common between these definitions of "totals" and "averages"? Do you see any pattern in these definitions? What is the key word that unites all of them?". I hope that after an objective investigation you will agree with me that the answer to all three questions above is "OUTPUT".

At this point our reader can ask legitimate questions:" Why this is the case? What is the reason for that?". As we have seen above, the main block on which the theory of costs is built in those textbooks is the Production Function $\mathrm{Q}=\mathrm{f}(\mathrm{L}, \mathrm{K})$. Dependent variable Q (“OUTPUT") plays a key role there. As a result, all different definitions of costs naturally come out from the Production Function and they are tightly fastened to the variable Q. Graphical representation of that situation is given below in Figure 1.

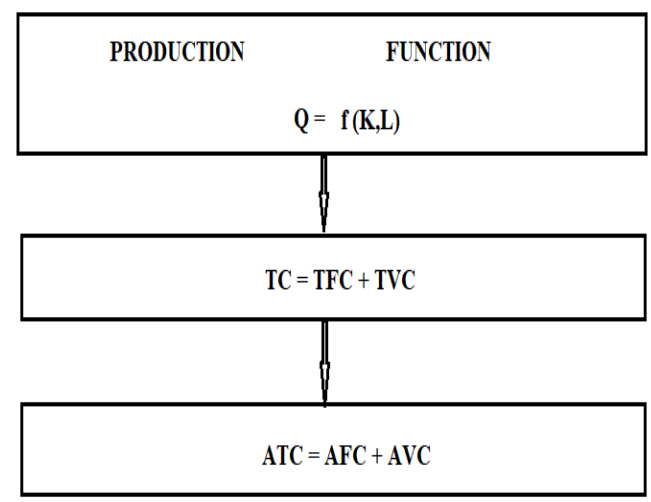

Figure 1. Graphical representation

Therefore, from the beginning the textbook puts into the mind of an undergraduate student an idea about strong correlation between "output" and "costs". The idea that "output" has "costs" is strengthened later on when the authors present the graphical relationship between different cost curves. 


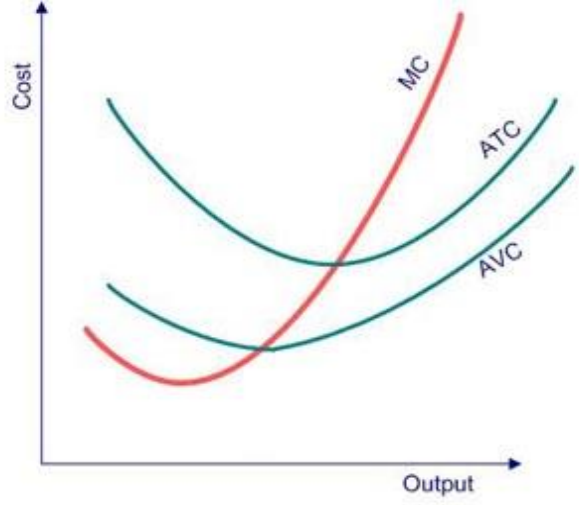

Figure 2. The cost of production concept using "The Traditional Approach"

Look at the famous graph in Figure 2 which is known practically to every undergraduate student who studied the cost of production concept using "The Traditional Approach" - you will see "output" on the horizontal axes and "cost" on the vertical. At this point we are ready to make a final logical step in our discussion. It is known that the notion of "output" is a particular form of the generalized notion of "things". Taking that into account we can conclude that the G. Mankiw's textbook that represents "The Traditional Approach" inevitably creates in the mind of an undergraduate student a firm idea that "things have costs".

\section{Do "Things" Have Costs? The Economic Way Of Thinking}

Students that learnt the concept of the costs of production by "The Traditional Approach" were trained well enough not to miss raw materials, labour time, the machinery or tools when they do calculation of costs of production. They also know how to express the value of these inputs in monetary terms. They were taught that the sum of these values is the cost of production of a good in question (remember how well John Smith responded to the owner's question about the dollar value of the costs of production of a kitchen box). "The Economic Way of Thinking" teaches that the calculation the costs of production that way is not necessarily wrong. But it leaves one very important question unanswered: "Why did it cost the producers whatever it did cost, in monetary terms, to use these inputs?" [12]. The reason why "The Traditional Approach" to the theory of costs of production was impotent to shed light on the above question is that "The Traditional Approach" takes into consideration only quantitative side of the theory leaving aside the most important qualitative side of it-opportunity cost- which reflects the deep economic nature of the costs of production. "The Economic Way of Thinking" - on the other hand- teaches that " the concept of opportunity cost asserts that the amount of money a producer must pay for any resource, human or physical, will depend upon what the owner of that resource can obtain from someone else, and this amount will depend upon the value of what that resource can create for someone else" [12]. Therefore, the value of foregone opportunities becomes the nature of the concept of costs of production.

The most fundamental area which serves as a borderline that separates "The Traditional Approach "from "The Economic Way of Thinking" with respect to the concept of production costs is the relationship between "actions" and "things". Figure 3 provides a visual illustration of the difference between the two approaches.

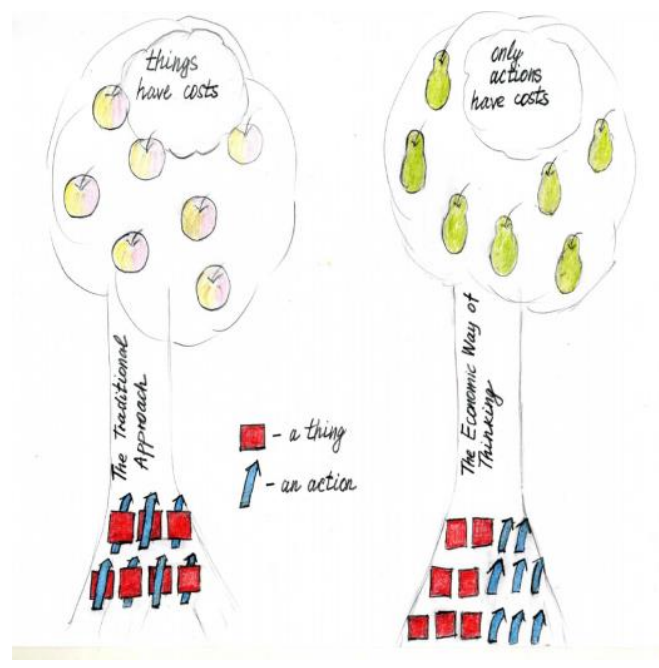

Figure 3. Visual illustration of the difference between the two approaches

The figure above shows that the economic soil where "actions" and "things" are merged together inevitably produces its fruit - the idea that "things have costs". The tree of "The Economic Way of Thinking" is rooted in totally different type of soil where "actions" are separated from "things". Therefore, it produces totally different type of a fruit - the idea that "things" have no costs at all. Only "actions" have.

Contrary to the common sense which teaches that things do have real" costs, "The Economic Way of Thinking" points out that "things cannot have costs. Only actions have" [12]. Paul Heyne defines the nature of the concept of " cost of an action" :"The real cost of any action ( going to a movie, buying a pair of jeans, manufacturing a lawnmower, moving to Halifax, raising beef cattle, building a hardware store, taking out an insurance policy) is the value of the alternative opportunity that must be sacrificed in order to take the action... The real costs that dollars represent are the opportunities given up when the money is spent in one way rather than another" [12]. 


\section{Conclusion}

Worldly experience of our hero John Smith forms in his consciousness a spontaneous notion that "things have costs". The Traditional Approach to teaching Production Costs strengthens this false idea. The Economic Way of Thinking as alternative approach to teaching Introductory Economics disarms this false notion and teaches that "things" do not have "costs". Only actions have.

The Economic Way of Thinking suggests some practical advices to those confronted with some questions about "costs". First of all, before making any conclusions about dollar value of costs we need to ask ourselves "To Whom" these costs are applied. Secondly, after you figured out the question "To Whom" you must turn your attention to a Relevant Action which that person will be performing. Applying consistently this approach to different economic settings you will form in your mind a proper economic way of thinking about multitude of real life issues associated with "costs".

\section{References}

[1] Anbu, T., (2014). Psychiatry made easy. Jaypee Brothers Medical P.

[2] Baldwin, D., (1983). All about children. Oxford: Oxford University Press.

[3] Berger, K. S., (2011). The developing person through the lifespan (8th ed.). New York: Worth Publ.

[4] Bjorklund, D., (2004). Children's Thinking: Cognitive Development and Individual Differences. Stamford: Wadsworth Publishing.

[5] Bruner J.S., (1971).The Relevance of Education. New York : W. W. Norton \& Company

[6] Bruner, J. S., (1966).Toward a theory of instruction. Cabridge, Mass.: Belkapp Press.

[7] Dasen, P., (1994). Culture and cognitive development from a Piagetian perspective. In W.J. Lonner \& R.S. Malpass (Eds.), Psychology and culture. Boston: Allyn and Bacon.

[8] Dworetzky, J., (1987). Introduction to child development. St. Paul: West Pub. Co.

[9] Faber, A., Mazlish, E., (2012). How to Talk So Kids Will Listen \& Listen So Kids Will Talk. New York: Simon $\&$ Schuster Inc.

[10] Frank, R., Bernanke, B., (2012). Principles of Microeconomics, 4th ed., Mc-Graw Hill Education.

[11] Helen, B., Boyd, D., Johnson P., (2006). Lifespan Development. 2nd Canadian ed., Pearson Education Canada Inc., Toronto.
[12] Heyne, P., Palmer, J., (1995). The Economic Way of Thinking, 1st Canadian ed., Pearson Education.

[13] Hull. C.L., (1943). Principles of Behavior: An Introduction to Behavior Theory. D. Appleton-Century Company.

[14] Keating, D., (1979). Adolescent thinking. In J. Adelson (Ed.), Handbook of adolescent psychology, pp. 211-246. New York: Wiley.

[15] Keenan, T., Evans, S., Crowley, K., (2016). An Introduction to Child Development. London: SAGE Publications Ltd.

[16] Lathey, N., Blake, T., (2014). Small Talk: How to Develop Your Child's Language Skills from Birth to Age Four. New York: Workman Publishing, Inc.

[17] Lewin, K., (1935). A dynamic theory of personality. New York: McGraw-Hill.

[18] Lewin, K., (1936). Principles of topological psychology. New York: McGraw-Hill.

[19] Lewin, K., (1938). The conceptual representation and measurement of psychological forces. Durham, NC: Duke University Press.

[20] Lewin, K., (1951). Field theory in social science. New York: Harper.

[21] Lott, D.M., (2015). Super Star Speech. London: Super Star DML Publishing.

[22] Lypsey, R., Chrystal, K., (2007). Economics. 11th ed. Oxford University Press.

[23] Mankiw, G., (2009). Principles of Microeconomics. 5th ed. South-Western Cengage Learning, USA).

[24] Meumann E., (2017). The Psychology of Learning. Andesite Press.

[25] Piaget, J., (1932). The moral judgment of the child. London: Routledge \& Kegan Paul.

[26] Piaget, J., (1936). Origins of intelligence in the child. London: Routledge \& Kegan Paul.

[27] Piaget, J., (1945). Play, dreams and imitation in childhood. London: Heinemann.

[28] Piaget, J., (1952). The origins of intelligence in children. New York: International Universities Press.

[29] Pica, R., (2015). What If Everybody Understood Child Development?: Straight Talk About Bettering Education and Children's Lives. London: SAGE Publications Ltd.

[30] Ray, D.C., (2015). A Therapist's Guide to Child Development: The Extraordinarily Normal Years: Routledge. 
[31] Shatkin, J.P. (2015). Child \& Adolescent Mental Health: A Practical, All-in-One Guide. New York: W.W. Norton \& Company.

[32] Siegel, D.J., Bryson, T.P. (2012). The Whole-Brain Child: 12 Revolutionary Strategies to Nurture Your Child's Developing Mind. New York: Bantam Books.

[33] Siegel, D.J., Bryson, T.P. (2016). No-Drama Discipline: The Whole-Brain Way to Calm the Chaos and Nurture Your Child's Developing Mind. New York: Bantam Books.

[34] Siegler, R. S., DeLoache, J. S., \& Eisenberg, N. (2003). How children develop. New York: Worth.

[35] Skinner, B. F. (1938). The Behavior of organisms: An experimental analysis. New York: Appleton-Century.

[36] Thorndike, E. L. (1905). The elements of psychology. New York: A. G. Seiler.

[37] Vygotsky, L. (1986). Thought and Language. Newly revised and edited by Alex Kozulin. (Original 1934) Cambridge - MA: The MIT Press.

[38] Vygotsky, L. S. (1978). Mind in Society. The Development of Higher Psychological Processes. Edited by M. Cole, V. John-Steiner, S. Scribner \& E. Souberman. Cambridge: Harvard University Press.

[39] Vygotsky, L. S. (1978). Mind in society: The development of higher psychological processes. Cambridge, MA: Harvard University Press.

[40] Vygotsky, L. S. (1986). Thought and Language (A. Kozulin, Trans.). Cambridge, Massachusetts: The MIT Press.

[41] Wadsworth, B. J., (2004). Piaget's theory of cognitive and affective development: Foundations of constructivism. Longman Publishing.

[42] Wood, C., (2018). Yardsticks: Child and Adolescent Development Ages 4 - 14, 4th Edition: Center for Responsive Schools, Inc.

[43] Выготский, Л.С., (1999). Педагогическая психология. Москва: Эксмо.

[44] Выготский, Л.С., (2005). Психология развития ребенка. Москва: Эксмо.

[45] Выготский, Л.С., (2005). Психология развития человека. Москва: Эксмо.

[46] Гезелл, А., (1930). Умственное развитие ребенка. Москва: Л.

[46] Залкинд, А.Б., (1926). Вопросы советской педагогики.Ленинград.

[47] Мейман, Э., (1913). Экономика и техника памяти. М.: "Космос".
[48] Павлов, И.П.,(1951). Двадцатилетний опыт объективного изучения высшей нервной деятельности (поведения) животных. Полн.собр.соч., т.3. Москва.

[49] Торндайк, Э., (1925). Принципы обучения, основанные на психологии. Москва. 